\title{
Peningkatan Kualitas Bungkil Inti Sawit Dengan Fermentasi Terhadap Aktivitas Enzim Dan Kandungan Zat Makanan
}

\author{
Mirnawati \\ Jurusan Nutrisi Makanan Ternak Fakultas Peternakan Universitas Andalas, Padang
}

\begin{abstract}
The present work was aimed to study the effect of temperature and time of incubation of palm kernel cake fermented with A. niger on the activity of enzymes and nutrient content. The experiment was arranged in completely factorial design of $3 \times 3$ patterns. The first factor was three levels of temperature of $30,37,44^{\circ} \mathrm{C}$, the second were three different times of incubation of 4,6 , and 8 days. Parameter observed included cellulose and protease activities, crude protein and crude fiber contents. Results showed that there was a significantly interaction between temperature and incubation times $(P<0,01)$ on enzyme activity of cellulose and protease and crude protein, but time of fermented were significantly $(P<0,05)$ on crude fiber of palm kernel cake fermentation. It was concluded that the optimum temperature and time of incubation were $30^{\circ} \mathrm{C}$ and 6 day, which gave the highest content of crude protein $(27,70 \%)$ and crude fiber $(17,73 \%)$.
\end{abstract}

Key words: palm kernel cake fermented, activity of enzymes and nutrient content.

\section{Pendahuluan}

Bungkil inti sawit (Palm Kernel Cake) merupakan hasil ikutan dari proses pengolahan inti sawit menjadi Palm Kernel Oil (PKO). Ketersediaan bungkil inti sawit (BIS) selalu meningkat disepanjang tahun sejalan dengan perkembangan industri minyak sawit. Tahun 2004 luas perkebunan kelapa sawit 273 ribu/Ha dengan kapasitas produksi minyak sawit mentah mencapai 644.384 ton dan bungkil inti sawit 141.764 ton (Badan Pusat Statistik Sumatera Barat, 2004).

Berdasarkan bahan kering bungkil inti sawit mengandung protein kasar yang cukup tinggi yaitu $18,67 \%$, serat kasar $21,75 \%$, lemak kasar $6,05 \%$, abu 4,81 \% dan BETN $38,45 \%$ (Hasil Analisa Laborotorium Teknologi Industri Pakan, 2005).
Masalah pada bungkil inti sawit adalah rendahnya kualitas nilai gizi secara biologis yaitu rendahnya daya cerna protein $(53 \%)$ pada unggas. Keadaan ini diakibatkan oleh tingginya kandungan serat kasar yang menyebabkan ketersediaan zatzat gizi rendah, karena molekul serat kasar melindungi molekul protein sehingga sukar diuraikan oleh protease unggas, sehingga bungkil inti sawit tidak tersedia bagi unggas (Babjee, 1989). Untuk meningkatkan daya cerna BIS itu perlu suatu teknologi pengolahan yaitu dengan fermentasi.

Fermentasi dapat mengubah bahan pakan yang mengandung protein, lemak dan karbohidrat yang susah dicerna menjadi mudah dierna disamping dapat menghasilkan aroma yang disukai ternak (Poesponegoro, 1975). Fermentasi 
dilakukan dengan menggunakan kapang Aspergillus niger. Diharapkan bungkil inti sawit yang telah difermentasi dengan kapang Aspergillus niger dapat dimanfaatkan sebagai pakan alternatif. Aspergillus niger merupakan kapang penghasil enzim amilase, protease, gluko amilase, laktase, katalase, glukosa oksidase, lipase, selulase, hemiselulase dan pektinase (Suhartono, 1989).

Winarno dkk (1980) menyatakan bahwa kapang Aspergillus niger sangat baik untuk dikembangkan karena endosporanya tahan terhadap panas, mudah tumbuh dengan cepat, tidak memerlukan zat pemacu tumbuh dan tidak bersifat mycotoxic. Selulase dan amiloglusidase merupakan enzim yang dihasilkan oleh Aspergillus niger (Hardjo dkk 1989). Enzim sellulase yang dihasilkan kapang Aspergillus sangat baik dalam mengurai bahan tandan kosong sawit (http: //www.penerbit.ukm.my/fb52-.thml).

Menurut Frazier dan Westhoff (1984) ada beberapa faktor-faktor yang perlu diperhatikan dalam proses fermentasi yaitu dosis inokulum, lama fermentasi, suhu, $\mathrm{pH}$ dan kandungan gula, substrat (media fermentasi), mikroorganisme, dan kondisi fisik pertumbuhan. Kombinasi antara suhu dan lama fermentasi akan mempengaruhi kualitas zat makanan. Suhu optimum Aspergillus niger antara $35-37^{\circ} \mathrm{C}$, suhu minimum 6-8 ${ }^{\circ} \mathrm{C}$ dan suhu maximum antara $45-47^{\circ} \mathrm{C}$ (http://aspergillus-niger.com/).

Semakin lama waktu fermentasi akan menyebabkan semakin banyak zat makanan yang dirombak (Sulaiman, 1988).
Marlina (2004) mendapatkan bahwa fermentais substrat eceng gondok (Eichornia crassipes) menggunakan kapang Aspergillus sp suhu $50^{\circ} \mathrm{C}$ kandungan serat kasar menurun dari $24,6 \%$ menjadi $19,00 \%$. Sedangkan fermentasi serat sawit dengan Aspergillus niger perlakuan selama 4, 6, 8 hari didapatkan hasil yang terbaik dalam menurunkan serat kasar selama masa inkubasi 6 hari (p3m.dikti.org / abstrak HB/ Abstrak HB03.pdf-).

Untuk itu dilakukan suatu penelitian untuk mengetahui pengaruh suhu dan lama fermentasi terhadap aktivitas enzim selulase, serat kasar, aktivitas enzim protease, kandungan protein kasar dan lemak kasar bungkil inti sawit.

\section{Materi Dan Metoda Penelitian}

\section{A. Materi Penelitian}

Substrat yang digunakan dalam penelitian ini adalah bungkil inti sawit yang diperoleh dari PT. Usaha Inti Padang. Aspergillus niger sebagai inokulum, dan media yang digunakan adalah PDA (Patato Dextro Agar).

\section{B. Metode Penelitian}

Penelitian ini dilakukan secara eksperimen dengan menggunakan rancangan acak lengkap (RAL) pola faktorial $3 \times 3$ dengan 2 ulangan untuk setiap kombinasi perlakuan. Faktor pertama adalah suhu fermentasi (A), yaitu $\mathrm{A} 1\left(30^{\circ} \mathrm{C}\right), \mathrm{A} 2$ $\left(37^{\circ} \mathrm{C}\right)$, A3 $\left(44^{\circ} \mathrm{C}\right)$. Faktor kedua adalah lama fermentasi (B), yaitu B1 (4 hari), B2 (6 hari), B3 (8 hari). Untuk mengetahui pengaruh perlakuan digunakan analisis ragam dan bila terdapat perbedaan yang nyata maka dilakukan uji lanjut 
Duncan's Multiple Range Test (DMRT) menurut Steel and Torrie (1995). Peubah yang diamati adalah aktivitas enzim sellulase, kandungan serat kasar dan PK bungkil inti sawit fermentasi.

\section{Hasil Dan Pembahasan}

Rataan aktivitas enzim selulase, kandungan serat kasar, aktivitas enzim protease dan kandungan protein kasar bungkil inti sawit fermentasi (BISF) selama penelitian dapat dilihat pada Tabel 1 .

Hasil analisis keragaman menunjukkan bahwa interaksi antara suhu dan lama fermentasi memberikan pengaruh berbeda sangat nyata $(\mathrm{P}<0,01) \quad$ terhadap aktivitas enzim sellulase bungkil inti sawit fermentasi. Hasil uji DMRT menunjukkan aktivitas enzim sellulase bungkil inti sawit fermentasi pada perlakuan A2B2 (suhu $37^{\circ} \mathrm{C}$ dan lama 6 hari) memberikan pengaruh berbeda sangat nyata $(\mathrm{P}<0,01)$ lebih tinggi dari perlakuan lainnya, yaitu 71,38 unit $/ \mathrm{ml}$. Tingginya aktivitas enzim sellulase pada suhu $37^{\circ} \mathrm{c}$ dan lama 6 hari merupakan kombinasi terbaik kapang Aspergillus niger bagi pertumbuhan dan produksi enzim sellulase dengan aktivitas yang makin meningkat. Menurut Fardiaz (1988) pada kondisi baik sel akan membelah dengan cepat dan konstan. Kapang berada dalam fase pertumbuhan cepat (fase logaritmik).

Tabel 1. Rataan Aktivitas Enzim Sellulase (Unit/Ml), Kandungan Serat Kasar (\%), Aktivitas Enzim Protease ( Unit/Ml) Dan Kandungan Protein Kasar (\% Bahan Kering)

\begin{tabular}{cccccc}
\hline \multirow{2}{*}{ Parameter } & Suhu & \multicolumn{3}{c}{ Lama Fermentasi } & \multirow{2}{*}{ Rataan } \\
\cline { 3 - 5 } & Fermentasi & $\mathrm{B} 1$ & $\mathrm{~B} 2$ & $\mathrm{~B} 3$ & \\
\hline Aktivitas & $\mathrm{A} 1$ & $36,57^{\mathrm{Ba}}$ & $23,46^{\mathrm{Ab}}$ & $14,22^{\mathrm{Ca}}$ & 34,75 \\
enzim & $\mathrm{A} 2$ & $32,05^{\mathrm{Ba}}$ & $71,38^{\mathrm{Aa}}$ & $14,79^{\mathrm{Ca}}$ & 39,41 \\
selulase & $\mathrm{A} 3$ & $13,37^{\mathrm{Bb}}$ & $29,20^{\mathrm{Ac}}$ & $12,85^{\mathrm{Ba}}$ & 18,47 \\
(unit/ml) & Rataan & 27,33 & 51,35 & 13,95 & \\
\hline Serat & $\mathrm{A} 1$ & 19,95 & 17,89 & 17,24 & 18,36 \\
Kasar $(\%)$ & $\mathrm{A} 2$ & 19,63 & 16,97 & 16,83 & 17,81 \\
& $\mathrm{~A} 3$ & 19,05 & 18,34 & 18,02 & 18,47 \\
& Rataan & $19,54^{\mathrm{A}}$ & $17,73^{\mathrm{B}}$ & $17,36^{\mathrm{B}}$ & \\
\hline Aktivitas & $\mathrm{A} 1$ & $13,93^{\mathrm{Bc}}$ & $24,49^{\mathrm{Ab}}$ & $14,44^{\mathrm{Bc}}$ & 17,62 \\
enzim & $\mathrm{A} 2$ & $22,75^{\mathrm{Ba}}$ & $31,15^{\mathrm{Aa}}$ & $31,09^{\mathrm{Aa}}$ & 28,33 \\
protease & $\mathrm{A} 3$ & $16,49^{\mathrm{Bb}}$ & $20,61^{\mathrm{Ac}}$ & $20,87^{\mathrm{Ab}}$ & 19,32 \\
(Unit/ml) & Rataan & 17,72 & 25,45 & 22,13 & \\
\hline Protein & $\mathrm{A} 1$ & $24,11^{\mathrm{Ba}}$ & $27,70^{\mathrm{Aa}}$ & $26,38^{\mathrm{Aa}}$ & 26,06 \\
kasar (\%) & $\mathrm{A} 2$ & $24,83^{\mathrm{Aa}}$ & $26,05^{\mathrm{Aab}}$ & $25,72^{\mathrm{Aa}}$ & 25,53 \\
& $\mathrm{~A} 3$ & $25,20^{\mathrm{Aa}}$ & $24,42^{\mathrm{ABb}}$ & $22,77^{\mathrm{Bb}}$ & 24,13 \\
& Rataan & 24,71 & 26,06 & 24,96 & \\
\hline
\end{tabular}

Keterangan: Superskrip huruf besar yang berbeda pada baris yang sama dan huruf kecil yang berbeda pada kolom yang sama menunjukkan berbeda sangat nyata $(P<0,01)$ 
Pada fase pertumbuhan cepat aktivitas enzim sellulase yang dihasilkan juga meningkat dalam merombak sellulase menjadi molekul yang lebih sederhana yaitu glukosa. Rendahnya aktivitas enzim sellulase pada perlakuan A1B1 (suhu $30^{\circ} \mathrm{C}$ dan lama fermentasi 4 hari), A2B1 (suhu $37^{\circ} \mathrm{C}$ dan lama fermentasi 4 hari) dan $\mathrm{A} 3 \mathrm{~B} 1$ (suhu $44^{\circ} \mathrm{C}$ dan lama fermentasi 4 hari) dibandingkan dengan $\mathrm{A} 2 \mathrm{~B} 2$ (suhu $37^{\circ} \mathrm{C}$ dan lama fermentasi 6 hari) karena kapang Aspergillus niger berada pada fase pertumbuhan awal dimana glukosa yang terdapat pada substrat diperlukan untuk pertumbuhan kapang dan pembelahan sel. Lebih rendahnya aktivitas enzim sellulase pada perlakuan $\mathrm{AlB} 3$ (suhu $30^{\circ} \mathrm{C}$ dan lama fermentasi 8 hari), A2B3 (suhu $44^{\circ} \mathrm{C}$ dan lama fermentasi 8 hari), A2B3 (suhu $37^{\circ} \mathrm{C}$ dan lama fermentasi 8hari) dan A3B3 (suhu $44^{\circ} \mathrm{C}$ dan lama fermentasi 8 hari) karena dipengaruhi oleh semakin tuanya kapang. Secara visual terjadi perubahan warna kapang Aspergillus niger dari hitam menjadi coklat kehitam-hitaman. Semakin tua kapang maka aktivitas enzim sellulase semakin rendah, diduga kapang menuju fase kematian yang ditandai dengan perubahan warna menjadi kecoklatan (Rifai, 1969).

Hasil analisis keragaman menunjukkan bahwa tidak ada interaksi antara suhu dan lama fermentasi terhadap kandungan serat kasar bungkil inti sawit fermentasi, begitu juga suhu fermentasi memberikan pengaruh yang berbeda tidak nyata $(P>0,05)$. Sedangkan lama fermentasi memberikan pengaruh berbeda sangat nyata $(\mathrm{P}<0,01)$ terhadap kandungan serat kasar bungkil inti sawit fermentasi.
Hasil uji DMRT menunjukkan kandungan serat kasar bungkil inti sawit pada perlakuan B1 (lama fermentasi 4 hari) serat kasar bungkil inti sawit feremntasi sangat nyata $(\mathrm{P}<0,01)$ lebih tinggi dibandingkan perlakuan B2 (lama fermentasi 6 hari) karena pada perlakuan B1 (lama fermentasi 4 hari) pertumbuhan kapang Aspergillus niger belum tumbuh subur secara sempurna sehingga aktivitas enzim belum bekerja secara aktif. Sedangkan pada perlakuan B2 (lama fermentasi 4 hari), kapang yang tumbuh ini menghasilkan enzim sellulase lebih aktif bekerja merombak sellulosa menjadi glukosa. Sesuai pendapat Shurtleff dan Aoyagi (1979) semakin lama waktu yang digunakan untuk proses fermenasi maka semakin banyak karbohidrat yang dirombak menjadi glukosa. Dilanjutkan Sulaiman (1988) bahwa semakin lama waktu inkubasi maka semakin banyak zatzat makanan yang dirombak. Antara perlakuan B2 (lama fermentasi 6 hari) dengan B3 (lama fermenasi 8 hari) berbeda tidak nyata $(\mathrm{P}>0,05)$. Hal ini disebabkan pada perlakuan B3 (lama fermentasi 8 hari) kapang Aspergillus niger sudah mulai tua, akibatnya aktivitas enzim kurang aktif bekerja.

Hasil analisa ragam menunjukkan bahwa terdapat interaksi antara suhu dengan lama fermentasi yang memberikan pengaruh berbeda sangat nyata $(\mathrm{P}<0,01)$ terhadap aktivitas enzim protease. Begitu juga masing-masing faktor suhu dan lama fermentasi memberikan pengaruh berbeda sangat nyata $(\mathrm{P}<0,01)$ terhadap aktivitas enzim protease BISF. 
Hasil uji DMRT terhadap interaksi antara suhu dan lama fermentasi menunjukkan bahwa pada suhu $30^{\circ} \mathrm{C}$ aktivitas enzim protease berbeda sangat nyata $(\mathrm{P}<0,01)$ meningkat dari lama 4 hari ke 6 hari, kemudian terjadi penurunan kembali pada lama 8 hari. Pada suhu $37^{\circ} \mathrm{C}$ dan $44^{\circ} \mathrm{C}$, aktivitas enzim protease berbeda sangat nyata $(\mathrm{P}<0,01)$ meningkat dari lama 4 hari ke 6 hari kemudian pada lama 8 hari sama dengan 6 hari. Pada lama fermentasi 4 hari dan 6 hari jika ditingkatkan suhunya dari $30^{\circ} \mathrm{C}$ menjadi $37^{\circ} \mathrm{C}$ terjadi peningkatan aktivitas enzim protease secara sangat nyata dan pada suhu $44^{\circ} \mathrm{C}$ terjadi penurunan aktivias enzim protease yang sangat nyata $(\mathrm{P}<0,01)$.

Pada suhu $44^{\circ} \mathrm{C}$ pada lama 4,6 dan 8 hari terjadinya penurunan aktivitas enzim protease karena semakin tinggi suhu dan lama fermentasi yang digunakan akan menyebabkan produk menjadi kering karena sebagian air akan mengalami penguapan yang akan menyebabkan substrat menjadi kering, pertumbuhan kapang menurun dan enzim yang dihasilkan sedikit sehingga aktivitas enzim protease menurun. Hal ini sesuai dengan pendapat Fardiaz (1988) bahwa suhu yang terlalu tinggi dapat menyebab kematian sel dan pembentukan enzim ekstra seluler berlangsung lebih baik pada keadaan suhu lebih rendah dari suhu yang optimum bagi pertumbuhannya.

Dari hasil yang didapatkan terlihat bahwa aktivitas enzim protease yang tertinggi terdapat pada suhu $37^{\circ} \mathrm{C}$. Hal ini disebabkan kapang Aspergillus niger bersifat mesofilik yang tumbuh baik pada suhu optimum yaitu $30^{\circ} \mathrm{C}$. Pada suhu $37^{\circ} \mathrm{C}$ ini kapang berada pada fase pertumbuhan cepat (fase logaritmik) dimana pada fase ini pembelahan sel sangat cepat mengikuti kurva logaritmik (Fardiaz, 1992) sehingga aktivitas enzim protease yang dihasilkan juga meningkat. Sesuai dengan pendapat Suhartono (1989) bahwa enzim protease biasanya diproduksi selama fase logaritmik atau mendekati pasca logaritmik.

Hasil analisis ragam (lampiran 3) menunjukkan adanya interaksi antara suhu dan lama fermentasi yang memberikan pengaruh berbeda sangat nyata $(\mathrm{P}<0,01)$ terhadap kandungan protein kasar BISF, begitu juga dengan faktor suhu yang memberikan pengaruh berbeda sangat nyata, sedangkan lama fermentasi memberikan pengaruh berbeda nyata $(\mathrm{P}<0,01)$ terhadap kandungan protein kasar BISF.

Hasil uji DMRT, terhadap interaksi antara suhu dan lama fermentasi menunjukkan bahwa pada suhu $30^{\circ} \mathrm{C}$ kandungan protein kasar sangat nyata $(\mathrm{P}<0,01)$ meningkat dari lama 4 hari ke lama 6 hari tetapi berbeda tidak nyata $(\mathrm{P}>0,05)$ dari waktu 6 hari ke 8 hari. Pada suhu $37^{\circ} \mathrm{C}$ dan $44^{\circ} \mathrm{C}$ baik pada lama 4,6 dan 8 hari kandungan protein kasar berbeda tidak nyata $(\mathrm{P}>0,05)$.

Bila dilihat dari lama fermentasi 4 hari dan 6 hari kandungan protein kasarnya berbeda tidak nyata $(\mathrm{P}>0,05)$ seiring dengan meningkatnya suhu baik pada suhu $30^{\circ} \mathrm{C}$ dan $44^{\circ} \mathrm{C}$. Pada lama 8 hari kandungan protein kasarnya berbeda tidak nyata $(\mathrm{P}>0,05)$ dari suhu $30^{\circ} \mathrm{C}$ ke suhu $37^{\circ} \mathrm{C}$ sedangkan pada suhu $44^{\circ} \mathrm{C}$ dengan lama fermentasi 8 hari terjadi penurunan protein kasar yang sangat nyata $(\mathrm{P}<0,01)$. 
Dari hasil yang didapat terlihat bahwa kandungan protein kasar yang terbaik adalah pada suhu $30^{\circ} \mathrm{C}$ dengan lama 6 hari, yaitu 27,70\%. Hal ini disebabkan kapang berada pada fase pertumbuhan cepat (logaritmik) serta tumbuh dengan subur dan merata diseluruh substrat sehingga kapang akan semakin aktif dalam menghasilkan enzim yang akan mengubah komponen penyusun media menjadi suatu massa sel yang akan dimanfaatkan untuk pertumbuhan dan perkembangbiakan kapang, sehingga terbentuk protein yang berasal dari tubuh kapang itu sendiri yang menyebabkan kandungan protein BISF meningkat (Sukara dan Atmowidjojo, 1980). Sesuai pendapat Saono (1976), bahwa tubuh kapang mengandung protein sekitar $31-50 \%$.

Pada suhu $44^{\circ} \mathrm{C}$ dengan waktu 8 hari didapatkan kandungan protein kasar terendah. Hal ini disebabkan semakin lama waktu fermentasi dan meningkatnya suhu dapat menyebabkan substrat menjadi kering, pertumbuhan kapang sudah mulai menurun, dimana kapang sudah ada yang mati dan kemungkinan protein teroksidasi menjadi $\mathrm{NH}_{3}$ sehingga kandungan protein kasar BISF rendah. Hal ini sesuai dengan pendapat Fardiaz (1988) bahwa lama fermentasi yang singkat mengakibatkan terbatasnya kesempatan kapang untuk terus berkembang sehingga komponen substrat yang dapat diubah menjadi massa sel juga sedikit, tetapi dengan waktu yang lebih lama berarti kesempatan bagi kapang untuk tumbuh dan berkembangbiak sampai mencapai fase stasioner dimana laju pertumbuhan sama dengan nol dan jumlah massa sel total pada fase tersebut konstan.

\section{Kesimpulan}

Berdasarkan hasil penelitian diperoleh kesimpulan bahwa perlakuan yang terbaik yaitu pada waktu 6 hari dengan suhu fermentasi $30^{\circ} \mathrm{C}$ dapat meningkatkan aktivitas enzim sellulase dan protease yaitu 71,38 unit $/ \mathrm{ml}$ dan 31.15 unit $/ \mathrm{ml}$ serta kandungan serat kasar dan protein kasar yaitu $27,70 \%$ dan $17,73 \%$.

\section{Daftar Pustaka}

Aritonang, D. 1984. Pengaruh Penggunaan Bungkil Inti Sawit dalam Ransum Babi yang Sedang Tumbuh. Disertasi Fakultas Pasca Sarjana. IPB Bogor.

Badan Pusat Statistik, 2004. Indonesia.

Buckle, et al. 1987. Ilmu Pangan. Terjemahan., Adiana dan $\mathrm{H}$. Purnomo. Penerbit UI Press Jakarta.

Bobjee, A.M. 1989. The use of palm kernel cake as animal feed. FOA Regional Office for Asia and The Pasifik (RAPA), Bangkok.

Fardiaz, S. 1988. Fisiologi Fermentasi. PAU. IPB dengan LSI. IPB, Bogor.

1992. Mikrobiologi Pangan I. Pusat Antar Universitas Pangan dan Gizi IPB, Bogor.

Http://aspergillus-niger.com/: diakses tanggal 20 Juli 2006 pukul 16.20 WIB. 
Http://schimmelschimmelpilze_de/schimmel pilz/aspergillus-niger.html : diakses tanggal 20 Juli 2006 pukul 15.55 WIB.

Http://www.penerbit.ukm.my//fb521.html : diakses tanggal 20 Juli 2006 pukul 16.35 WIB.

Marlina, Leni. 2004. Pengaruh Suhu dan Lama Fermentasi dengan Aspergillus $s p$ terhadap $\mathrm{pH}$, Kandungan Serat Kasar dan
BETN Eceng Gondok (Eichornia crassipes). Skripsi Fakultas Peternakan Universitas Andalas, Padang.

P3m.dikti.org/abstrakHB/AbstrakHB 03.pdf- : diakses tanggal 23 Juli 2006 pukul 14.45 WIB.

Steel, R.G.D. dan J.H. Torrie. 1995. Prinsip dan Prosedur Statistik. Edisi Bahasa Indonesia. PT. Gramedia. Jakarta.

Alamat korespondensi: Ir. Mirnawati, MS Jurusan Nutrisi Makanan Ternak, Fakultas Peternakan Universitas Andalas, Kampus Limau Manis, Padang Telp. 0751-74208 Fax: 0751-71464.

Diterima: 5 April 2007, Disetujui: 21 Mei 2007 